I. А. Кравцова, Л. Р. Шпачук

\title{
СПЕЦИФІКА ФОРМУВАННЯ В УЧНІВ 2 КЛАСУ ІНТЕРЕСУ ДО ВИВЧЕННЯ РІДНОЇ МОВИ
}

Кравцова I. А., Шпачук Л. Р. Специфіка формування в учнів 2 класу інтересу до вивчення рідної мови.

У статті розглядається проблема становлення пізнавального інтересу до уроків рідної мови в учнів початкової школи. Зацікавлення учнів початкової школи інтересу рідною мовою - це довготривалий процес, що відбувається поетапно. Стійкий пізнавальний інтерес формується при поєднанні емоційного, раціонального й ефективного в навчанні.

Ключові слова: формування інтересу, вивчення рідної мови, умови формування інтересу, розв'язання педагогічних проблем.

Кравцова И. А., Шпачук Л. Р. Специфика формирования в учеников 2 класса интереса к изучению украинского языка.

В статье рассматривается проблема становления познавательного интереса к урокам украинского языка в учащихся начальной школы. Заинтересованность учащихся начальных классов родным языком - это длительный процесс, который осуществляется планомерно и поэтапно. Стойкий познавательный интерес формируется в единстве эмоционального, рационального и эффективного в обучении.

Ключевые слова: формирование интереса, изучение украинского языка, условия формирования интереса, решение педагогических проблем.

Kravcova I. A., Shpachuk L. R. Specificity of formation in the schoolboys of 2 forms of interest to study of the Ukrainian language.

The article presents the problem of formation of cognitive interest to lessons of the Ukrainian language in elementary school. The interest of elementary school pupils by the native language is a long process, which is carried out systematically and stage by stage. Proof cognitive interest is formed in unity of emotional, rational and effective in learning.

Key words: formation of interest, study of the Ukrainian language, conditions of interest formation, decision of pedagogical problems. 
Функція сучасної школи полягає в тому, щоб сформувати в $\dddot{1}$ вихованців стійкий інтерес до процесу пізнання $[4,69]$.

Інтерес дітей до навчання - велика рушійна сила, яка відкриває розум i серце дитини для благотворного впливу наук. Завдяки інтересу дитяча думка послідовно проникає в суть явища чи предмета, наполегливо відшукує зв'язки, i, переборюючи перешкоди, досягає радісного осяяння, коли невідоме відкривається в усій логічній цілісності і красі. Здобута ціною праці і творчих зусиль, поєднана з особистим життєвим досвідом істина у свідомості школяра перетворюється у власне переконання. А це означає, що досягнуто основної мети навчання: учень не тільки збагачується знаннями, а й розвивається і формується його особистість.

Таким чином, виховання інтересу до навчальної діяльності є одним 3 головних чинників ефективності навчально-виховного процесу $[5,17]$.

Певний внесок у розробку теоретичних основ пізнавального інтересу зробили Л. С. Виготський, М. Ф. Добринін, С. Л. Рубінштейн, Д. Б. Ельконін, Л. І. Божович, Г. І. Щукіна, В. О. Сухомлинський, О. Я. Савченко та інші. У дослідженнях доведено, що становлення і розвиток інтересу до певного виду діяльності виступає як складний динамічний, багатоплановий процес [7, 109].

Для формування інтересу учнів до навчання важливе значення має форма викладу матеріалу вчителем. Так, уроки, у процесі яких говорить переважно вчитель, а учні пасивно слухають, не сприяють виробленню у школярів глибокого й стійкого інтересу до знань. I, навпаки, уроки, під час яких забезпечуються широкі можливості для вияву активності і caмостійності учнів, великою мірою стимулюють розвиток пізнавальних інтересів [3, 98].

Яскравість, емоційність, різноманітність видів робіт якісно доповнюють змістовний урок, який викликає самостійний пошук дитини, активність його допитливого розуму, розвиток волі, адже захопленість на уроці - це зовсім не синонім розважання, а навпаки, напружена праця і постійний пошук.

Формування в учнів початкової школи інтересу до рідної мови - це довготривалий процес, що відбувається поетапно. Стійкий пізнавальний інтерес формується при поєднанні емоційного, раціонального й ефективного в навчанні. Тому так важливо серйозне заняття зробити цікавим і захоплюючим.

Розглянемо основні умови виникнення та розвитку інтересу школярів до навчання:

- організація навчання, за якої учень захоплюється процесом самостійного пошуку і “відкриттям” нових знань, розв’язує задачі проблемного характеру;

- навчальна робота, як і будь-яка інша, цікава тоді, коли вона різноманітна (одноманітна інформація і схожі дії швидко викликають нудьгу); 
- необхідне розуміння потреби, важливості, доцільності вивчення предмета загалом;

- чим більше новий матеріал пов'язаний з раніше отриманими знаннями, тим зрозуміліший і цікавіший він для учнів;

- дуже легкий і дуже складний матеріал не викликає інтересу (навчання повинно бути складним, але доступним);

- учневі цікавіше працювати тоді, коли його робота перевіряється частіше (у тому числі ним самим);

- яскравість наочності до навчального матеріалу, емоційна реакція $\mathrm{i}$ зацікавленість самого вчителя з разючою силою впливають на учня, на його ставлення до предмета $[1,15]$.

Наведеному вищу комплексу умов при правильній організації відповідають активні форми і методи навчання.

Однією з умов формування пізнавального інтересу є впровадження в шкільну практику методів, які викликають позитивні дії та настрій - цікавість, здивування, моральні переживання.

Пізнавальний інтерес на початковій стадії формується під впливом емоційних чинників. Для створення емоційної ситуації важливими є вдало дібрані приклади з літератури, художніх фільмів, особистісних переживань вчителя $[6,90]$.

Найбільш вагомими складовими інтересу до роботи вчителя початкової школи, до творчих підходів щодо розв'язання педагогічних проблем $\epsilon$ такі, що не можна залишити поза увагою, а саме:

- пізнавальна спрямованість, яка характеризує притаманний інтересу процес поглибленого вивчення предмету, явища або факту;

- позитивна емоційна спрямованість, що свідчить про значущість і позитивне ставлення до об'єкта дослідження;

- сталість, що характеризує тривалість і перевагу над іншими інтересами;

- особливість, яка визначає найкращу увагу та активну взаємодію особистості з об'єктом дослідження;

- галузь інтересу як основна сфера його прояву, що й обумовлює існування цього інтересу.

Адекватна оцінка сутності інтересу й осмислення самого процесу його становлення неможливі, по-перше, без правильного розуміння його природи і динаміки i, по-друге, без урахування особливостей професії вчителя, специфіки педагогічної діяльності, іiї характеру і спрямованості, які змінюються $з$ часом.

Великий інтерес і зацікавленість викликають уроки, проведені в нестандартній формі. Це можуть бути уроки-подорожі, екскурсії, уроки народознавчого характеру, інтегровані уроки, мовні вікторини, зустрічі з казковими героями тощо $[2,125]$.

Отже, в основі формування пізнавальних інтересів учнів початкової школи на уроках рідної мови лежить система активізації мовленнєвих і ро- 
зумових сил дитини, іiі вольових зусиль під час розв'язування навчальних завдань. Але цей процес неможливий без одночасної активності всього класного колективу і піднесення ролі особистості школяра в ньому, створення відповідної організації колективних форм діяльності на уроці, які сприяють самоствердженню дитини в очах дорослих і однолітків.

\section{Література}

1. Кравцова I. А. Нестандартний урок як засіб розвитку пізнавальної активності школярів: [методичний посібник]. - Кривий Ріг: КДПУ, 2000. - С. 3-18.

2. Кравцова I. А. Пізнавальна активність молодшого школяра як основа формування проблемно-пізнавального інтересу учнів на уроках рідної мови // Кравцова I. А., Юрчишина О. Г. / Збірник наукових праць студентів КДПУ. - Кривий Ріг: КДПУ, 2006. - №9. - С. 125.

3. Кравцова І. А. Різні підходи до визначення поняття "інтерес" у психологопедагогічній літературі / Збірник наукових праць. - Х., 1997. - С. 97-100.

4. Логачевська С. П. Дійти до кожного учня. - К.: Рад. школа, 1990. - С. 51-134.

5. Савченко О. Я. Розвиток пізнавальної самостійності молодших школярів. - К.: Рад. школа, 1982. - 179 с.

6. Формування інтересу до навчання у школярів / За ред. Маркової А. К. - М.: Педагогіка, 1986. - $96 \mathrm{c.}$

7. Щукина Г. И. Педагогические проблемы формирования познавательного интереса учащихся. - М.: Педагогика, 1988. - 208 с. 